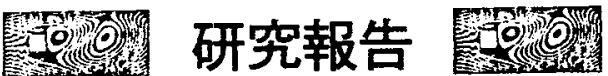

\section{建設工事中の風による災害に関する現状分析 \\ Study on Wind-Induced Accidents of Civil Structures during Construction}

\author{
大幢 勝利*1 アーサン・カリーム*2 藤野 陽三*3 \\ Katsutoshi 0HD0, Ahsan Kareem, Yozo FUJINO
}

\section{SUMMARY}

On the basis of the yearbooks of the Japan Construction Safety and Health Association, wind-induced structural accidents during construction were investigated on the death and serious accidents where more than 3 people were killed or injured. These data were compared with data of overseas wind-induced accidents collected from Engineering News-Record. The wind-induced structural accidents were classified according to the accident types, and their countermeasures for safety were examined.

From the investigation, it was found both in Japan and overseas that the collapse accidents during construction have the high rate in the whole construction accidents and about $10 \%$ of the serious collapse accidents were due to wind. Furthermore, it was also found that in Japan the ratio of the collapse accidents due to wind had not been changed since 1970, and the countermeasures for the prevention of the collapse accidents were proposed.

\section{1.はじめに}

建設工事は屋外作業が多いため天候の影響を受けやす く, 強風や大雨等の悪天候時には作業を中止し安全対策 を施している。通常, 作業中止の判断は現場に任せられ ており，風雨により溶接に欠陥が生じるなど品質に関わ るため作業を中止する場合もあれば，雨により足下が滑 る，風にあおられバランスを崩すなど，荌全性を考慮し
て作業を中止する場合もある。悪天候による作業中止 の判断を誤った場合, 品質に関わるものは施工後の梌查 により宿を兒つけ出しやり直すことができる。一力， 安全対策を䛱った場合，一度災害が発生すれば人命に関 わることなので, 取り返しのつかないものになることが 多い。過去においては，強風による足場などの倒堎災害 が多発しており，これらの中には多数の死偒者を出す「重

\footnotetext{
* 1 労㗢省産業安全研究所 研究員

Research Engineer, National Institute of Industrial Safety, Ministry of Labour, Japan.

*2ノートルダム大学工学部土木工学科長 教授 Ph.D

Ph.D, Robert M, Moran Professor of Civil Engineering and Chair, Department of Civil Engineering and Geological Sciences, University of Notre Dame, U.S.A.

*3 東京大学大学院工学系研究科社会基盤工学専攻 教授 Ph.D

Professor, Ph.D, Graduate School of Engineering, University of Tokyo.

(原稿受理: 承成 11 年3月24日)
} 
大災害」(一時に3名以上の死第者を伴う災害) に発展 したものも多くあった。

これらのことから，天候の中で特に風についての安全 対策は重要視されてきた。事実, 風による足場の倒填災 害の事例調查や風荷重の算定方法に関する研究 ${ }^{11}$ がなさ れ，続いて，風荷重に対する鋼管足場等の安全技術指針 ${ }^{2)}$ が制定された。しかし，近年においても強風による足場 等の倒壊災害は俄然として発生しており，新聞䉻上をに ぎわすこともある。このような状況から，従来の方法で は風による災害防止に限界があると考えられるため, 新 たな安全対策を講じることも必要である。そのために は, 現在と過去における建設工事中の風による災害の発 生状況の変化を調查し，問題点を指摘することにより， 風に対する安全対策を再度見直すことが必要である。

そこで, 本研究では，(1) 1997 年以前の10年間と 1980 年以前の過去 10 年間に建設業において発生した労㑬炎 害における，風による死亡炎害や重大災害の発生状況を 調查し, 過去から現在までの風による労微災害の発生状 況の変化を調へる。(2) さらに,このような労湖災害中 心の分析に加え，統計的には把握しづらい建設工事に起 因する風による公衆災害についても事例的に分析する。 （3）また，海外にも目を向けて調查し，我が国と海外で 発生した災害事例を比較することにより，共通の問題点 を指摘する。(4)これらの調查の結果から, 現在の建設
工事中の風による災害の問題点の指摘を行い, 今後の災 害防止対策について検討することを目的とする。

\section{2. 我が国の建設業における風による労儌災害}

我が国の建設業における労働災害の中で, 風が原因と 思われる死亡災害・重大災害の発生状況を, 建設業安全

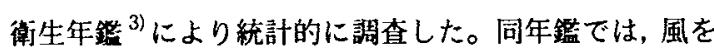
キーワードとして災害の分類がなされていないため，年 爁に示されている死亡災害・重大災害の全発生状況（重 大災害では交通事故を除く）より，風が原因と思われる 災害を抜き出し調查した。

なお，本章では“建設工事中の災害”ではなく“建設 業における労㗢災害”として調査したが,ここでいう建 設業における「労湖災害」とは，建設業に従事する人が 災害によって死賃することを意味するものであり，建設 工事とは関係ない災害, 例えば事務所内での食中毒など も含むものとしている。一方, 建設工事中の災害でも， 足場の倒壊等により通行人など建設業とは関係ない第 三者が死賃した場合には、「公䍃災害」としてここでは 含まないものとしている。これは，建設業安全衛生年鑑 のデータが建設業という業種単位で分類されているこ と,および労做災害についてのみ扱われていることによ るものであり, 建設工事中の災害として一元化されたデー タベースが他に無いためである。

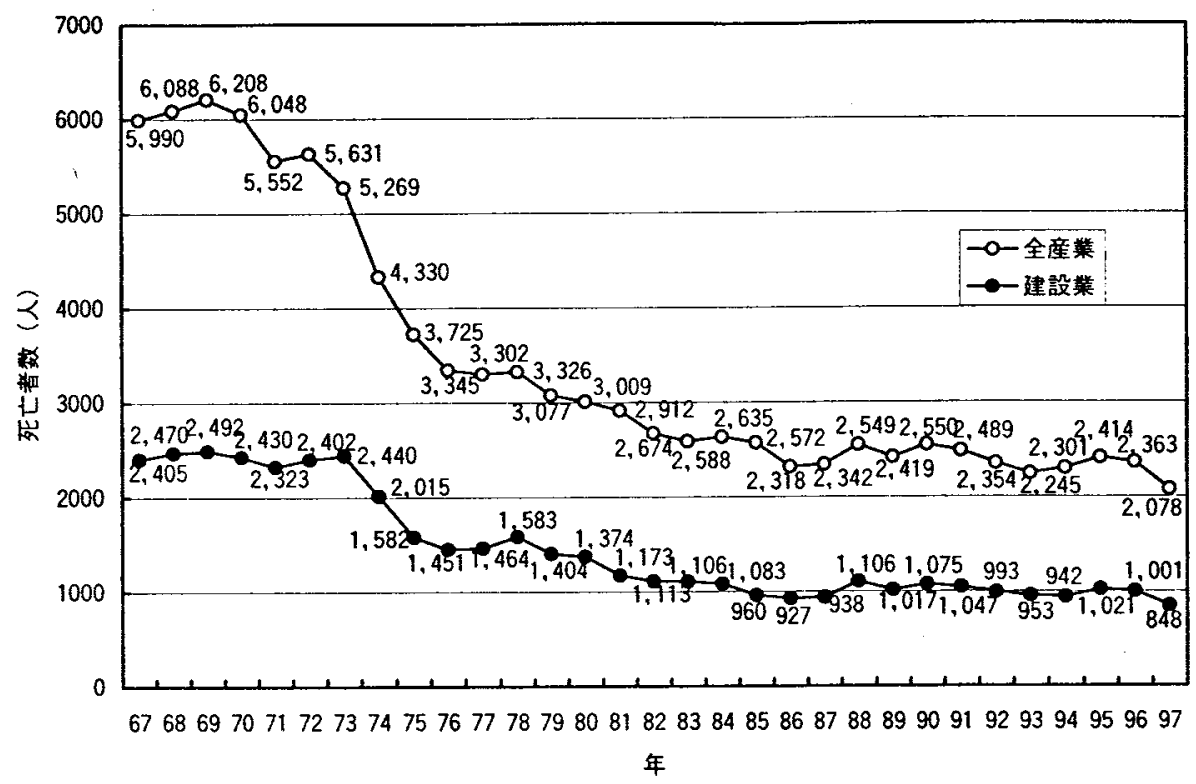

Fig. 1 我が国の全産業と建設業における死亡者数の推移

Variation of number of deaths in whole and construction industry in Japan. 


\section{1 建設業における死亡災害・重大災害の㚆吾}

Fig. 1は1967年から1997年までの, 全産業と建設業 における死亡者数の推移を示したものである。Fig. 1より，全産業における死亡者数のうち建設業の占める 割合は約 4 割とっここ 30 年間ほぼ一定の割合で推移し ている。また，建設業では，1969年の 2,492 人をピーク に1973年から急速に死亡者数が隇少しているが,これ は1972年に制定された労㗢安全衛生法により安全対策 が強化されたためである。しかし，1985年に1,000人 を割ってからは死亡者数の減少傾向に歯止めがかかり， それ以降は 1,000 人前後で現在まで推移している。なお， 1997 年は 848 人と若干少なくなっているが, 労働省の 発表では安全管理体制が定着したこと,および近年の景 気後退により工事量が隇少したことを理由として挙げ ている。しかし，安全管理体制が突然向上したとも考え にくく，あと数年は動向を同う必要がある。

一方，Fig. 2は1967年から1997年までの，全産業と 建設業における重大災害の発生件数の推移を示したも のである。Fig. 2 上り，全産業における重大災害発生件 数のうち建設業の占める割合は,ここ 30 年間約 $4 \sim 6$ 割 の間で推移している。また, 建設業では, 1968年の 250 件をピークに多少の変動はあるものの, 労衔安全衛生法 により1986年の67件まで咸少していったが，その後は 增減を繰り返して横这いになっている。

\section{2国による死亡災害}

Table 1は, 1988年から1997年までの近年 10 年間 において，建設業の中で風によって引き起こされた災害 による死亡者数を、災害の種類別に示したものである。 Table 1に示した風による丞落とは，主に作業員が風に あおられてバランスを朤して丞落したものを，風による 飛来・落下とは，主に建設資材が風により飛散して作業 員に激突したものを，風による倒壊とは，主に足場など の仮設構造物や建設中の構造物本体が風により倒塤し， 作業員がこれに巻き込まれたものを示す。

Table 1に示すように, 風による死亡者数の総計は 10 年間で57人であった。しかし，建設業全体に対する比 率でみると, 風による死亡者数の総計は 10 年間の合計 で建設業全体の $0.6 \%$ ，小さな割合となっている。ま た, 災害の種類別でるると風による烝落が 10 年間の合 計で最も多く，次に倒壊と飛来・落下の順となっている。 しかし，榇落全体の中で風による炎害の占める比率をみ

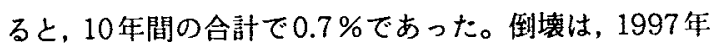
に風による災害の比率が $10.0 \%$ と高い割合を占めてい るが, 10 年間でみれば $2.5 \%$ とや小さな割合となって いる。同様に, 飛来・落下も $2.3 \%$ とや小さな割合と なっている。

これを，他の自然現象による死亡災害について調へる と，1996年は風による死亡者数が6人であるのに対し， 雪による雪朗などで 4 人, 雨により滑るなどで 2 人死亡

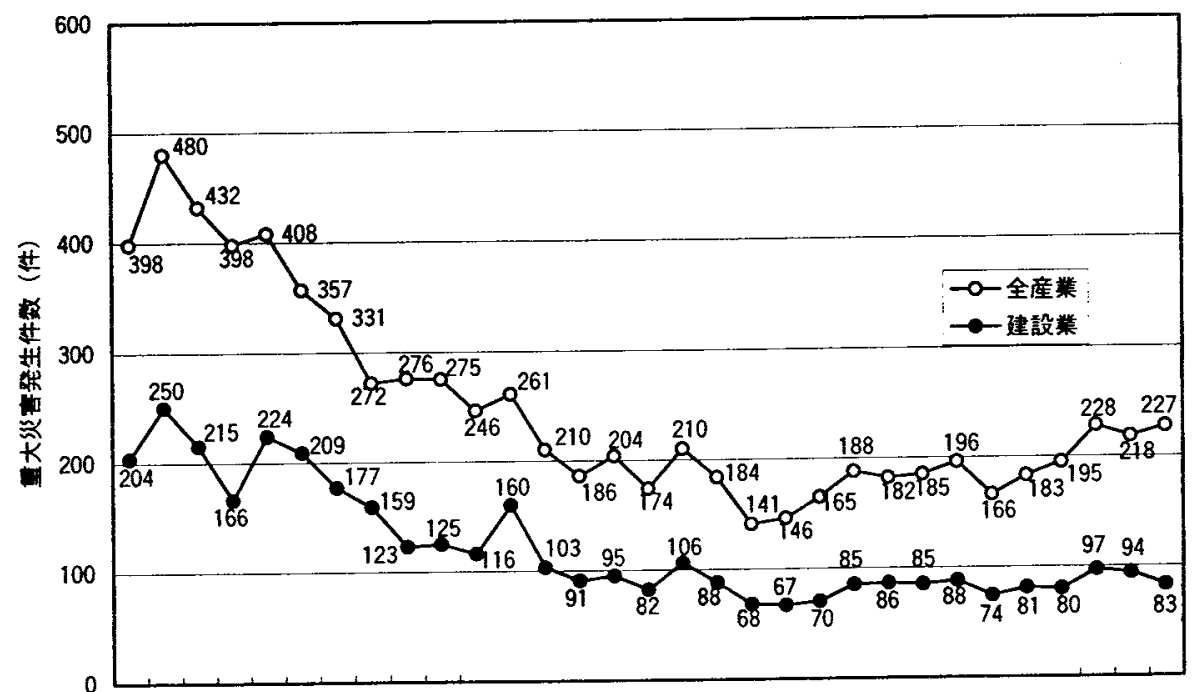

$67686970717273747576777879808182838485868788 \quad 899091929394959697$

年

Fig. 2 我が国の全産業と建設業における重大災害発生件数の推移

Variation of number of serious accidents in whole and construction industry in Japan. 
Table 1 我が国の建設業における風による死亡者数の推移 (人)

Variation of number of deaths by wind in construction industry in Japan.

\begin{tabular}{|c|c|c|c|c|c|c|c|c|c|c|c|c|}
\hline \multicolumn{2}{|c|}{ 災害の種類 } & 1988 & 1989 & 1990 & 1991 & 1992 & 1993 & 1994 & 1995 & 1996 & 1997 & 計 \\
\hline \multirow[t]{3}{*}{ 檠落 } & 全体 & 427 & 398 & 437 & 424 & 381 & 363 & 356 & 386 & 374 & 359 & 3905 \\
\hline & 風 & 5 & 1 & 3 & 1 & 0 & 4 & 3 & 4 & 2 & 4 & 27 \\
\hline & 比率 (\%) & 1.2 & 0.3 & 0.7 & 0.2 & 0.0 & 1.1 & 0.8 & 1.0 & 0.5 & 1.1 & 0.7 \\
\hline \multirow[t]{3}{*}{ 倒壊 } & 全体 & 32 & 49 & 49 & 57 & 59 & 47 & 29 & 45 & 51 & 30 & 448 \\
\hline & 風 & 0 & 3 & 2 & 0 & 1 & 2 & 0 & 0 & 0 & 3 & 11 \\
\hline & 比率 (\%) & 0.0 & 6.1 & 4.1 & 0.0 & 1.7 & 4.3 & 0.0 & 0.0 & 0.0 & 10.0 & 2.5 \\
\hline \multirow{3}{*}{$\begin{array}{l}\text { 飛来· } \\
\text { 落下 }\end{array}$} & 全体 & 42 & 56 & 58 & 52 & 52 & 56 & 45 & 38 & 29 & 56 & 484 \\
\hline & 風 & 0 & 1 & 1 & 1 & 1 & 2 & 0 & 2 & 2 & 1 & 11 \\
\hline & 比率 (\%) & 0.0 & 1.8 & 1.7 & 1.9 & 1.9 & 3.6 & 0.0 & 5.3 & 6.9 & 1.8 & 2.3 \\
\hline \multicolumn{2}{|c|}{$\begin{array}{l}\text { その他風による } \\
\text { 災害 }\end{array}$} & 1 & 0 & 0 & 1 & 1 & 1 & 2 & 0 & 2 & 0 & 8 \\
\hline \multicolumn{2}{|c|}{$\begin{array}{l}\text { 風による災害の } \\
\text { 絵計 }\end{array}$} & 6 & 5 & 6 & 3 & 3 & 9 & 5 & 6 & 6 & 8 & 57 \\
\hline \multicolumn{2}{|c|}{ 建設業全体 } & 1,106 & 1,017 & 1,075 & 1,047 & 993 & 953 & 942 & 1,021 & 1,001 & 848 & 10,003 \\
\hline \multicolumn{2}{|c|}{ 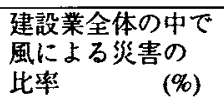 } & 0.5 & 0.5 & 0.6 & 0.3 & 0.3 & 0.9 & 0.5 & 0.6 & 0.6 & 0.9 & 0.6 \\
\hline
\end{tabular}

Table 2 我が国の建設業における重大災害 発生件数（1971 1980年, 件)

Number of serious accidents in construction industry in Japan from 1971 to 1980.

\begin{tabular}{|c|c|c|c|c|c|c|c|}
\hline \multicolumn{2}{|c|}{$\begin{array}{c}\text { 災害の } \\
\text { 種類 }\end{array}$} & 例轅 & 壁落 & $\begin{array}{c}\text { 土砂 } \\
\text { 崩壊 }\end{array}$ & $\begin{array}{c}\text { 交通 } \\
\text { 事故 }\end{array}$ & $\begin{array}{c}\text { その } \\
\text { 他 }\end{array}$ & 合計 \\
\hline $\begin{array}{c}\text { 発 } \\
\text { 生 } \\
\text { 件 } \\
\text { 数 }\end{array}$ & 全体 & 215 & 91 & 153 & 639 & 389 & 1,487 \\
\cline { 2 - 7 } & $\begin{array}{c}\text { 比率 } \\
(\%)\end{array}$ & 12.1 & 2.2 & 0.0 & 0.0 & 0.5 & 2.0 \\
\hline
\end{tabular}

している。同様に, 1997 年は風による死亡者数が8人 であるのに対し，雪による災害で 3 人，雨による災害で 2 人, 波浪による災害で 1 人死亡しており，自然現象によ る災害の中では風による死亡者数が最も多くなってい る。なお，その他の地震などによる死亡災害は発生して いなかった。これより, 建設業での風による災害は, 死 亡災害の発生割合としては小さいものの, 自然現象によ る災害に限っていえば, 最も死亡者数の多い災害である ことがわかった。

\section{3 風による重大苂害}

建設業における風によって引き起こされた重大災害に ついて分析する。「重大災害」とは，一時に3人以上が 死甥する災害であり，大規模なものが多く一度発生すれ ば人的・経済的損失は甚だしいものとなっている。こ
Table 3 我が国の建設業における重大災害 発生件数（1988 1997年, 件) Number of serious accidents in construction industry in Japan from 1988 to 1997.

\begin{tabular}{|c|c|c|c|c|c|c|c|}
\hline \multicolumn{2}{|c|}{$\begin{array}{c}\text { 災害の } \\
\text { 種類 }\end{array}$} & 倒壊 & 落 & $\begin{array}{l}\text { 土矽 } \\
\text { 崩壊 }\end{array}$ & $\begin{array}{l}\text { 交通 } \\
\text { 事故 }\end{array}$ & $\begin{array}{c}\text { その } \\
\text { 他 }\end{array}$ & 合計 \\
\hline \multirow{3}{*}{$\begin{array}{l}\text { 発 } \\
\text { 生 } \\
\text { 件 } \\
\text { 数 }\end{array}$} & 全体 & 76 & 77 & 39 & 464 & 197 & 853 \\
\hline & 風 & 9 & 1 & 0 & 0 & 1 & 11 \\
\hline & $\begin{array}{c}\text { 比率 } \\
(\%)\end{array}$ & 11.8 & 1.3 & 0.0 & 0.0 & 0.5 & 1.3 \\
\hline
\end{tabular}

のため，重大災害は社会的にも影響が大きく，重大災害 を減らすことが重要な課題となっている。

Table 2は, 1971年から1980年までの過去 10年間 における，建設業の重大災害発生件数を示したものであ る。また, Table 3は, 1988年から1997年までの近年 10 年間における, 重大災害発生件数を示したものであ る。Table 2,3より, 重大炎害の発生件数は雨者とも交 通事故が最も多くなっている。その次は，過去 10 年間 では倒壊，土砂崩壊の順になっているが，近年10年間で は烝落, 倒壊の順に変化している。交通事故が非常に多 いのは，建設業に携わる人の現場や会社に向かう途中の 交通事故など，建設工事とは全く関係ないものが大半を 占めているためである（例えば，作業員を載せたマイク ロバスが現場に向かう途中交通事故を起こし，3人以上 が死甥すれば重大災害となる)。交通事故を除いて，建 
設丁＼cjkstart徉に值接関連するもので考えれば，過去 10 年間で は倒壊が, 近年 10 年間では晸落と倒壊がほぼ同数で発 生件数が最も多くなっている。しかし, 㛥落の大半は構 造物の倒壊に起因する埜落であることから，近年におい ても倒壊の発生件数が最も多いものと考えられる。

このような状況の中, 風による重大災害について災害 の種類別に調べてみると, Table 2,3より過去も近年も ほとんどが倒㙵災害であった。これを発生件数で見る と，過去においては風による倒壊が 26 件であったのに 対し，近年では 9 件になり約 $1 / 3$ に滅少している。一方, 倒壊災寒全体の発生件数も215件から76件になり, 同 样に約 $1 / 3$ に減少している。よって, 倒壊全体の中で風 による災害の占める比率は, 過去も近年も約 $10 \%$ とな りほとんど变化がないことがわかった。

Fig. 2にも示したように, Table 2 (過去) からTable 3 (近年) の間に, 建設業における重大災害の発生件数 は著しく滅少したが,これは, 法体系の整備による近年 の始全管理体制の旮実や構造物の品質向上等の刘果と 考えられる。しかし，倒壊災害全体の中に占める風によ る災害の比滋が，過去も近年もほとんど変わっていない ということは，上記理由により倒壊災害全体の減少に伴 い風による災害も減少しただけであって，風対策が他の 交全対策に比べ特に改善されたわけではないと考えら れる。

\section{4 倒俵災害の荷重の方向別発生状況}

風による倒塤災害は，主に風による水平荷重に対し， 棈造物の水平方向への安定性が不足していることから 生じるものである。一方, 倒壊災害の中にはコンクリー 卜荷重などの鈆直荷重によって生じるものもあるが, 鉛 进荷重による倒㐭は，鉛㨁方向の強度不足によるのもの （支柆の夾屈等）と水平力向の安定性不足によるもの（転 (倒等) とに分けられる。そこで, Table 2 と Table 3に ホした重大災害のけで，倒壊災害を生じさせた荷重を方 们別に調へることにした。その結果，過去も近年も荷重 の才问別の比率にほとんど贸化がなく，鉿直荷重による 倒壊は90\%弱で, 水平荷而による倒壊は $10 \%$ 強であっ た。鈆直荷重 $90 \%$ の内訳は, 自重やコンクリート荷重 等に対する鈆遖万问の強度不足のものが約 $60 \%$ であっ た。…万控えワイヤ一の切断による転倒や水平変位を 防止する部材の不足など, 鉛直荷重しか作用していない にも関わらず水平方间の安定性不足によるものが約 30 \%であった。よってここ３０％と水平荷重による10\%
を合わせると，倒壊災害のうち約 $40 \%$ が構造物の水平 方向の安定性不足により発生したと推定される。そし て、この $40 \%$ \%うち約 10\%分（すなわち1/4）は風荷 重によるものである。なお，風荷重の中には，風の吹き 上げ，吹き下げにより鉛直荷重として㗢く場合もあるが, このような荷重による倒壊災害は見られなかった。ま た, Table 2,3に示した上砂崩壊災害の中で, 水平荷重 として土荷重を受けた土止め支保工の倒壊がみられた が、あくまで地盤より上の構造物の倒壊を対象とし、士 砂崩罗による倒壊は含めないこととした。

ここで, 水平荷重による倒壊の中で風荷重以外のもの について調べると,クレーンの吊り荷や工事車両が棈造 物に激笑するなどわずか数件しかなかった。これらは 水平荷重というよりはむしろクレーンや車両側の操作 に原因があるものばかりであり，それを除けば“水平荷 重による倒壊”イコール“風荷重による倒壊”と考え られる。このため, 水平荷重に対する倒壊対策としては, 風荷重に対する構造物の水平方向の安定性を重視する 必要がある。一方, 鈆直荷重による倒壊の内, 水平方向 の安定性不足による倒壊については，ほとんどが施工時 に鉛直荷重のみを考慮し，風荷重等の水平荷重を考慮し ていない不安定な構造物であっため発生したものであ った。このことについては，第5章で述べることとする。

\section{3. 海外における建設工事中の風による災害}

海外での建設工事に関連した風によって引き起こされ た災害を、アメリカで出版されている建設技術雑誌， Engineering News-Record (ENR) ${ }^{4)}$ によって調べ た。ENRは，1800年代後半から 100 年以上も続いてい る権威ある雑誌であるが,アメリカを中心に世界中の国々 で発生した建設工事に関連した災害が数多く掍載され ている。これらは社会的に影響の大きい重大な災害と 考えられるため，我が国の重大災害に们敵するものと思 われる。

Table 4は, ENRに1988年から1997年の10年開に おいて揭載された建設工事中の災害の件数を, 災害の㮔 類ごとに示したものである。Table 4より，建設工事全 体の合計が 133件であったのに対し，風による災害の合 計は12件で，その比率は $9.0 \%$ と高い割合を少めている。 また，災害の種類別でみると，倒壊が他に比べ圧倒的に 多く，海外においても倒壊災害は社会的に最も影響が大 きいものと考えられる。この倒塤災害の内, 風による倒 壊は全体の $9.2 \%$ を占めており, 我が国の重大災害の場 
合とほぼ同じ約 $10 \%$ でった。よって，建設工事に関 連した風による倒壊災害は, 我が国と海外の共通の問題 点であると考えられる。

\section{4. 建設工事中の風による倒壊災害事例}

以上の調查結果より，風による倒壊災害に絞って災害 事例の分析を行うこととする。

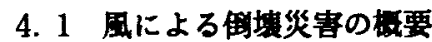

Table 5は1988年から1997年までの近年10年間に 発生した，我が国の建設業における重大災害の中で, 風 による倒壊災害の概要を示す。また, Table 6 はENR に1988年から1997年までの10年間に揭載された, 建

Table 4 ENRに掲載された建設工事に関連した 災害件数（1988年１997年, 件) Number of accidents, reported in ENR from 1988 to 1997.

\begin{tabular}{|c|c|c|c|c|c|c|c|}
\hline \multicolumn{2}{|c|}{$\begin{array}{c}\text { 災害の } \\
\text { 種類 }\end{array}$} & 倒壊 & タレ & $\begin{array}{l}\text { 飛. } \\
\text { 落下 }\end{array}$ & 慗落 & $\begin{array}{l}\text { その } \\
\text { 他 }\end{array}$ & 合計 \\
\hline \multirow{2}{*}{ 件 } & 全体 & 76 & 22 & 10 & 7 & 18 & 133 \\
\hline & 風 & 7 & 2 & 2 & 1 & 0 & 12 \\
\hline 数 & $\begin{array}{l}\text { 比率 } \\
(\%)\end{array}$ & 9.2 & 9.1 & 20.0 & 14.3 & 0.0 & 9.0 \\
\hline
\end{tabular}

設工事中の風による倒壊災害の概要を示す。

両者の発生状況から考えると, 風が原因の倒壊災害は 仮設の足場が倒壊したものと, 施工中の構造物本体が倒 壊したものとに分類することができる。我が国の場合， 足場の倒壊が 4 件で施工中の構造物本体の倒壊が 3 件で あった（その他，仮設のプレハブ小屋の倒壊 2 件)。ま た，ENRの記事の場合には，足場の倒壊が 2 件で施工中 の構造物本体の倒壊が 5 件であった。なお, Table 5, 6には，災害発生時の風速が把握できたものについての み示してあるが, 我が国の場合ほとんどが $20 \mathrm{~m} / \mathrm{s}$ 以下 の低い風速で倒壊しているのに対し，ENRの記事では 風速 $20 \mathrm{~m} / \mathrm{s}$ 以上の強風下での倒溒が目立っている。

我が国の場合は，道路や建物に近接した工事が多いた め, 飛来・落下物災害防止を目的として, 外周部に立て た足場にシートを張ることが多い。このため, 風荷重に 対する安全技術指針などにより,シートが受ける風荷重 に対し足場の安全性をチェックするように指導されて いる。この安全技術指針により施工す㧈ば，場所や高さ などにもよるが, 安全率を加味すると風速 $20 \mathrm{~m} / \mathrm{s}$ の風 では足場は倒壊しないようになっている。しかし, Table 5 のように $20 \mathrm{~m} / \mathrm{s}$ 以下の低い風速でも足場の倒壊が発 生しており，これは，施工時の安全管理が十分行われて いなかったためと思われる。一方, ENRの記事の場合， 風速 $20 \mathrm{~m} / \mathrm{s}$ 以上の強風により倒壊し多くの死傷者を出

Table 5 我が国の建設業における重大災害の中で風による倒壊災害の概要

Summary of serious collapse accidents by wind in construction industry in Japan.

\begin{tabular}{|c|c|c|c|}
\hline No. & 利壊した物 & 永害の概姴 & $\begin{array}{l}\text { 被桨 } \\
\text { 考数 }\end{array}$ \\
\hline 1 & 足埸 & 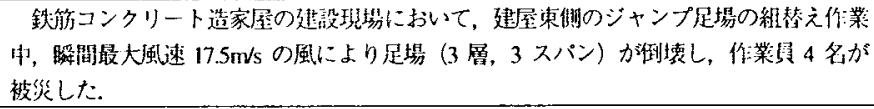 & 4 \\
\hline 2 & $\begin{array}{l}\text { 优設のプレ } \\
\text { ハフ小屌 }\end{array}$ & 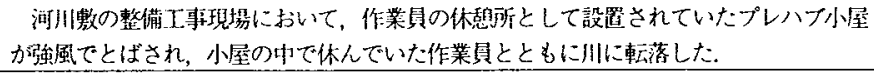 & 3 \\
\hline 3 & $\begin{array}{l}\text { 施工中の } \\
\text { 構造物本体 }\end{array}$ & 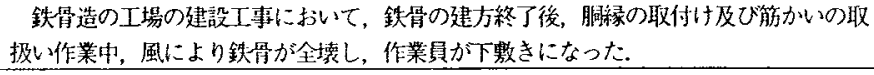 & 5 \\
\hline 4 & $\begin{array}{l}\text { 施工中 } \\
\text { 構造物本体 }\end{array}$ & 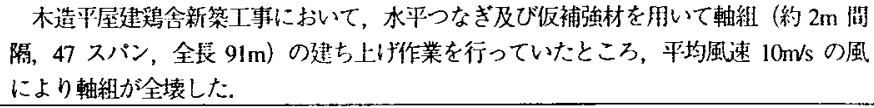 & 4 \\
\hline 5 & 足煋 & 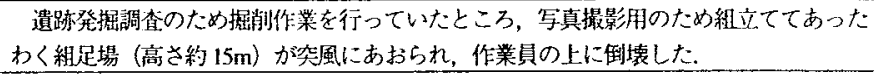 & 6 \\
\hline 6 & 足場 & $\begin{array}{l}\text { 体育祭の応援席（高さ } 6.8 \mathrm{~m} \text { ，長さ } 68 \mathrm{~m} \text { ) 設置工事において，わく組足場でステージ } \\
\text { の組立て作業中，平均風速 } 10 \mathrm{~m} / \mathrm{s} \text { の風のため組立て中のステージが倒壊した. }\end{array}$ & 5 \\
\hline 7 & $\begin{array}{l}\text { 仮設のプレ } \\
\text { ハフ小屋 }\end{array}$ & 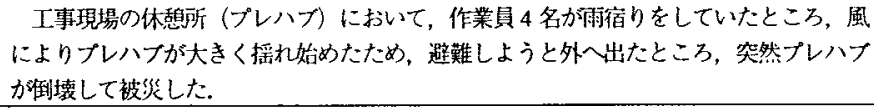 & 3 \\
\hline 8 & 足場 & 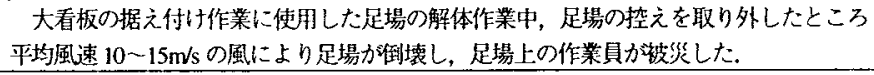 & 4 \\
\hline 9 & $\begin{array}{l}\text { 施工中の } \\
\text { 搆造物本体 } \\
\end{array}$ & 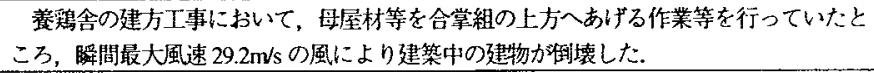 & 3 \\
\hline
\end{tabular}


Table 6 ENRに揭載された建設工事に関連した風による倒俵災害の概要

Summary of collapse accidents by wind, reported in ENR.

\begin{tabular}{|c|c|c|c|}
\hline No. & 倒壊した物 & 災害の概要 & $\begin{array}{l}\text { 被经 } \\
\text { 者数 }\end{array}$ \\
\hline 1 & $\begin{array}{l}\text { 施工中の } \\
\text { 構造物本体 }\end{array}$ & $\begin{array}{l}\text { 高速道路のオーバーパス建設現場において，風速 } 105 \mathrm{mph}(47 \mathrm{~m} / \mathrm{s}) \text { 以上の風により } 45 \mathrm{l} \\
\text { のコンクリートガーダーが吹き飛ばされ，その下の道路を走行していた車の上に落下 } \\
\text { し，運転手が被苂した }\end{array}$ & 2 \\
\hline 2 & 足場 & 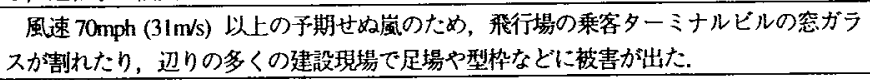 & 不明 \\
\hline 3 & $\begin{array}{l}\text { 施工中の } \\
\text { 楧造物本体 }\end{array}$ & $\begin{array}{l}\text { 空気膜ドームの建設中，強風によりドームの屋根が漼壊した．屋根は完全に空气で膨 } \\
\text { らむ前でままた，屋根を支えるシステムも完成前であった. }\end{array}$ & 0 \\
\hline 4 & $\begin{array}{l}\text { 施工中の } \\
\text { 構造物本体 }\end{array}$ & 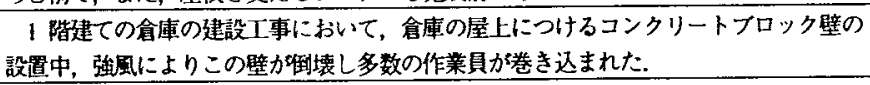 & 16 \\
\hline 5 & 足場 & 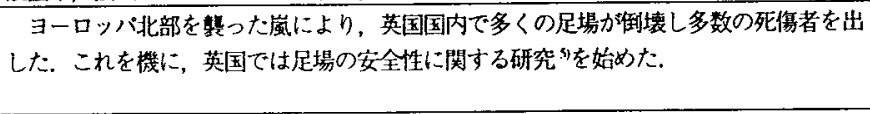 & $\begin{array}{l}100 \text { 以上 } \\
\text { (建标以 } \\
\text { 外含合) }\end{array}$ \\
\hline 6 & $\begin{array}{l}\text { 施工中の } \\
\text { 構造物本体 }\end{array}$ & $\begin{array}{l}\text { 銀行ビルの建設工事において，最低でも } 60 \mathrm{mph}(27 \mathrm{~m} / \mathrm{s}) \text { の強風により，完成した骨組 } \\
\text { みの3分の2か椡壤した }\end{array}$ & 0 \\
\hline 7 & $\begin{array}{l}\text { 施工中の } \\
\text { 構造物本体 }\end{array}$ & $\begin{array}{l}\text { 3 階建ての木造アパートの建設現場で，およそ50mph (22m/s)の強風により，2階より } \\
\text { 上の部分か淮壊した. }\end{array}$ & 11 \\
\hline
\end{tabular}

しているが，そのような强風下で作業をしていたこと自 体が問題である。このようなことは, 我が国の場合には ほとんどあり得ないことである。また，ENRの記事で は風による施工中の構造物本体の倒壊が多いが，これに 対してKarshenasらによって，鉄骨建て方中のビルの 强風に対する安定性に関する研究 ${ }^{6)}$ が行われ，有効な安 全対策が示されている。しかし，我が国ではこのような 研究は行われておらず，施工中の構造物本体の風に対す る安定性に関しては，全て施工業者任せになっている。

ここで,我が国において1971年から1980年の過去10 年間に発生した建設業における重大災害の中で, 風によ って引き起こされた倒壊災害について同様に調べると， 足場の倒壊が 6 伴で施工中の構造物本体の倒壊は 16 作 であった（その他，仅設のプレハブ小屋の倒壊4件）。こ れより，我が国の場合，1970年代から近年にかけて風に よる施工中の構造物本体の倒壊は発生件数が大きく減 少したが, 足場の倒壊は発生件数にほとんど变化がない ため，是場の風に対する安全対策が特に改善されたわけ ではないと考えられる。



建設工事川の風が原因と思われる災害の中で, 特に足 場の倒壊に対する安全対策があまり改善されていない ことがわかった。しかし、これらは労㗢災害の中で人的 損害が生じたものから得られた結果であり, 実際には物 的損害が生じたものや公栾災害となったものも多くあ る。そこで, 風が原因と思われる足場の倒壊の中で, 公

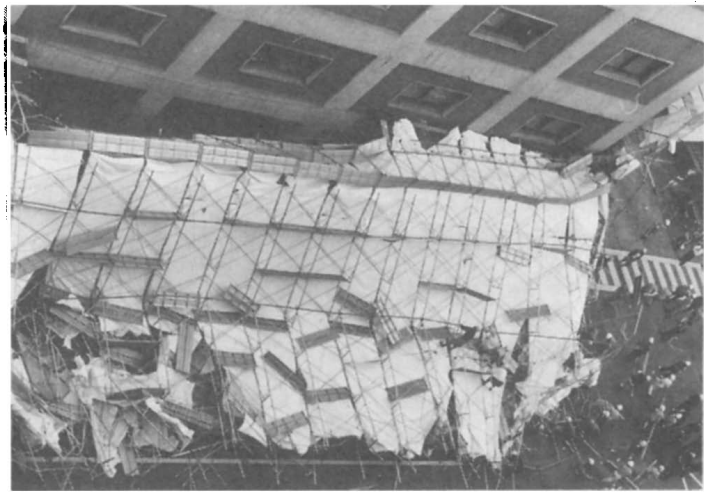

Photo. 1 倒壊した足埸の状況

Condition of collapsed scaffolds.

策災害に発展したものの事例を取り上げ問題点につい て考察する。

1) 事例 $1^{7)}$

(1) 災害の概要

ビル改修工事のため設置されたわく組足場が強風のた め道路上に倒壊し, 通行人等の 4 人が死䅞した。Fig. 3 に災害現場周辽の略図 ${ }^{8)}$ を示すが, 足場は図中斜線の ビルのA，B，C三面（図の太線）に沿って立てられてい た。このうち，Aの部分の足場が全面的に倒塤した。そ の時の様子をPhoto. 1 に示す。気象庁のデー夕から， 災害が発生した前 1 時間のこの付近の瞬間最大風速（風 向）は $16.3 \mathrm{~m} / \mathrm{s}$ (北北西, Fig. 3 に示す方问), 後 1 時 間では $13.0 \mathrm{~m} / \mathrm{s}$ (北北西) であった。また,この足場に はほぼ全面に養生シートが張られており，強風による風 


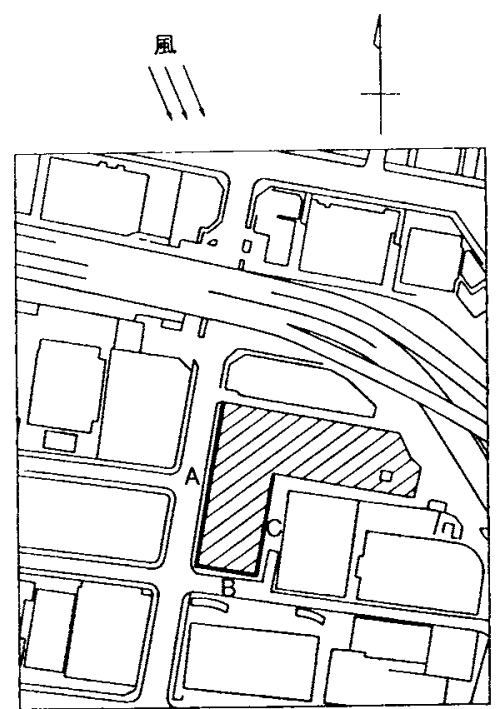

Fig. 3 災害現埸周辺の略図 Sketch of accident spot.

压力によって倒壊したものと思われる。

Fig. 4 に倒買した足場の断面図を示すが，高さは33. $55 \mathrm{~m}$ でわく組の 19 層分あり，A の部分は幅 $104.4 \mathrm{~m}$ で 58 スパンにも及んでいた。この足場には，通常の足場 と同样に，転倒防止のため建物との間に壁つな゙ぎが設け られていた。壁つなぎは，2層2スパン（垂直方向 $3.4 \mathrm{~m}$ ， 水平方向 $3.6 \mathrm{~m}$ ）毎に設置するように設計図面に示され ていたが，実際には垂直方向 $3.8 \sim 5.4 \mathrm{~m}$ ，水平方向 $3.6 \mathrm{~m}$ の間隔で設置されていた。この壁つなぎはFig. 5 に示 すように，羽子板型のアンカーボルトに緊結金具（通称 クランプと呼ばれ，雨者を合わせ羽子板クランプと呼ぶ） を取り付けたもので，これを建物側のコンクリートに埋 め込み，鋼管を介して足場側とクランプにより接続する 構造となっていた。

\section{（2）発生原因}

目揧者や丁事関係者の証言などから災害の状況を推察 すると，次のようであった。まず，足場の風上側側面か ら吹き込んだ風のため足場面に張られた養生シートが はらみ,この風圧力により足場の風上側上層部で，壁つ なぎの鋼管が羽子板クランプより滑って抜けることに より破壊した。さらに，壁つなぎの破壊が風下側上層部 に波及していき，続いて足場上首部がはがれその自重に より下層部の壁つなぎに破壊が波及していった。こ のような連鎖的な破塤により，最終的に足場全体が転倒 するように道路上に倒れたものと推察される。

以上より，災害の主な発生原因は次のように考えられ ている。

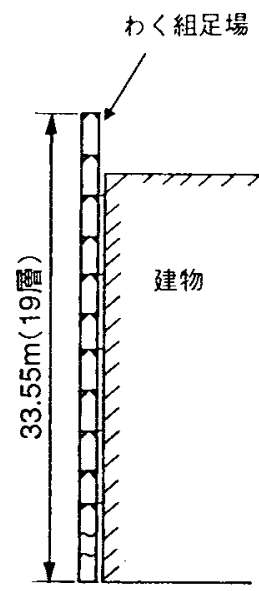

Fig. 4 倒壊した足場の断面図 Cross section of collapsed scaffolds.
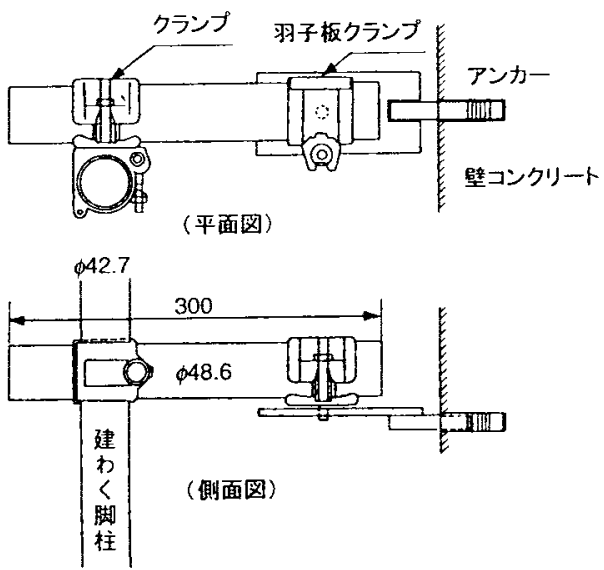

Fig. 5 災害で使用された壁つなぎ Tie used in the accident.

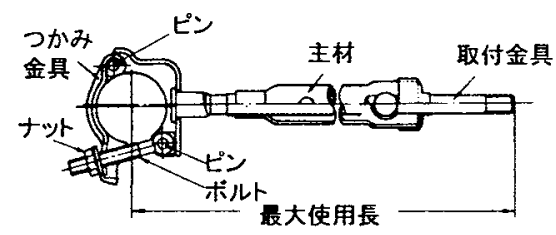

Fig. 6 壁つなぎ専用金具 Authorized tie for scaffolds.

(1)壁つなぎの引張・圧繀強度は，クランプと鋼管の摩擦 力によって決定される構造となっていた。このため,ク ランプの締め付け力によって性能が不確かとなり，Fig. 6に示す壁っなぎ専用金具に比へ風荷重に対する強度が 不足していた。 
(2)行政的には，強風時に養生シートを外すよう指導され ていたにも関わらず，養生シートを外さなかった。

2) 事例 2

\section{（1）災害の概要}

鉄骨 5 階建てビルの建設現場において,ブラケット足 場が倒壊し隣家の屋根の一部を損壊した。幸い，深夜に 災害が発生したため被災者はいなかった。災害発生当 時の瞬間最大風速は $17.2 \mathrm{~m}$ で比較的風が強く，風にあお られて倒壊したものと思われる。Fig. 7に倒壊した足 場の立面図を示すが, 5 層目から上が南側からねじれる ようにして倒れたものである。しかし，足場の北側部分 は，北側に立てられた足場に接綂されていたため倒壊を 免れた。

倒壊した足場は一側ブラケット足場と呼ばれ，支柱と 水平材を銅管パイプとクランプによって平面的に組み 立て，その構面の片側からブラケットを張り出し，その 上に板をかけ渡して足場とするものである。主に，低層 家屋の工事や，敷地が狭くて枠組み足場や本足場が設置 できない場合に使用される。

この足場は高さ $15.5 \mathrm{~m}$ の 8 層組みで, 地上から 2 首目
までは鋼矢板，2層目から 4 層目までは防災シート，4層 目から上はグリーンネットが張られていた。また，倒壊 した足場にはFig.7に示すように壁つなぎが取り付け られていた。4首目から下はほぼ2層2スパン毎に壁 つなぎが取り付けられていたが，4層目から上は3力所 (ほほ3首3スパン每, $5.4 \mathrm{~m} \times 5.4 \mathrm{~m}$ ) にしか取り付けら れておらず，その構造も垂木を番線で固定する簡易なも のであった。

(2) 発生原因

調查の結果, 災害の主な発生原因は以下のように考え られている。

(1)壁つなぎの取り付け間隔が法令の範囲内（当該足場 の場合，垂直方向 $5 \mathrm{~m}$, 水平方向 $5.5 \mathrm{~m}$ 以内）でなく，ま た，簡易な構造のため取り付け強度が不十分であった。 (2)強風によって,グリーンネットが強い風荷重を受けた が, 深夜のためそれに対する壁つなぎ等の補強ができな かったこと。（通常，強風時に盖生シートは巻き上げた り取り外したりするが,グリーンネットは取り外さない ことが多い。)

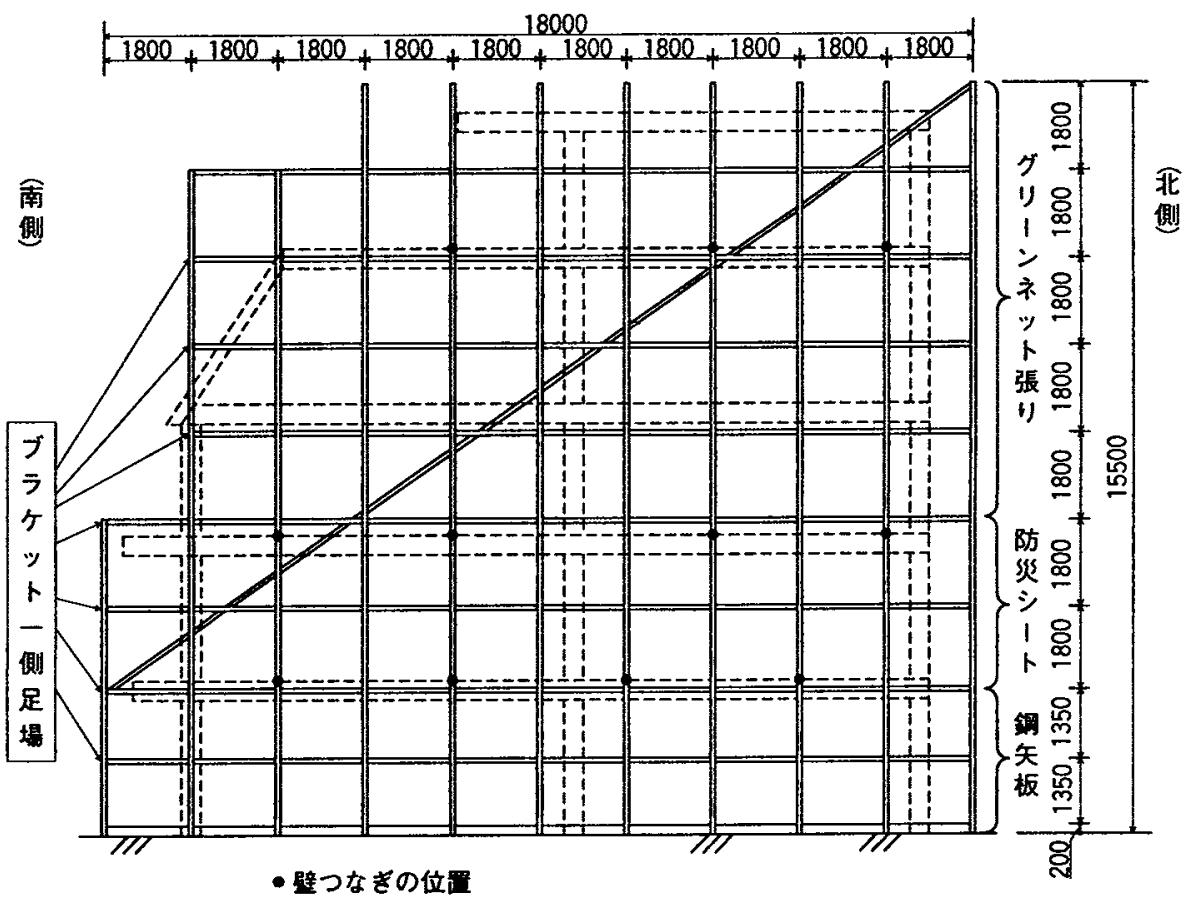

Fig. 7 倒壊した足場の構造 Collapsed scaffolds. 


\section{5. 考察}

\section{1 施工計画段腈の奖害防止対策}

事例 1 は風荷重に対する鋼管足場等の安全技術指針の 制定前に発生し，事例 2 は安全技術指針の制定後に発生 した災害である。事例 1,2 とも災害の発生原因は, 壁っ なぎの強度等が不十分であったこと, および強風時の安 全対策が不十分であったことがあげられる。特に事例 2 の場合, 壁つなぎの構造や取り付け間隔からして, 安 全技術指針が全く反映されていなかったといえる。こ のように, 両事例とも安全管理が不十分であったため発 生したものと考えられるが,このことは，風による倒壊 以外の多くの倒垻災害についてもいえることである。そ の他の倒壊災害に対する原因分析でも，施行計画段階に 安全性が十分検討されていなかった，足場や支保工など が組立図通りに組立てられていなかった，溶接の欠陥や 少化などにより部材の强度が不十分であった, 施工譟差 により支柱が傾いていた，コンクリートなどの荷重が不 均等であったなど施行計画時の安全対策や施工時の安 全管理が不十分であったことが指摘 ${ }^{9}$ されている。

施行計画段階での安全性の倹討不足による倒壊は, 施 工計画者が安全基準等を理解し，十分な知讙を身につけ ていれば防止できるものである。しかしながら，2.4節 で述べたように, 水平方向の安定性不足による倒壊につ いては，ほとんどが施工時の荷重として鉛直荷重のみを 考慮し, 水平荷重を考慮していない不安定な構造物であ ったため発生したものであった。これらの原因として は風荷重を含め水平荷重に対する施工計画者の認識不 足が一つの要因として考えられる。なぜなら, 完成後の 構造物は水平荷重として風荷重や地震荷重を考虑して 設計されているが，施工中の構造物，特に仮設構造物は 供用期間が短く, 施行計画時に考慮すべき水平荷重の大 きさを明確に定義することが困難なためである。

仮設構造物に考慮すべき水平荷重として，土木学会の 鋼構造架設設計指針 ${ }^{10)}$ や建築学会の期限付き構造物の 設計・施工マニュアル ${ }^{11}$ 等各種指針を見ると, 風荷重, 地震荷重, 照查水平荷重を見積もることが示してある。 しかし、各指針每に水平荷重の大きさが異なっていたり， 明確に定義されていないるのもあり暧昧となっている。 また，施工計画事例として「水平荷重が予想される場合

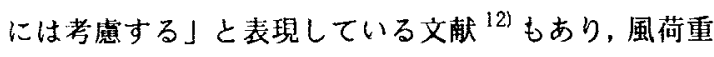
など水平荷重は発生頻度が少ないことから, 鉛直荷重に 此べ水平荷重に対する認識が薄くなっているものと考 えられる。しかし一方で, 2. 4 節では重大災害に発展し た倒壊災害の内，約 $40 \%$ が水平方向の安定性不足から
生じていたことから，風荷重など発生頻度が少なくても， 水平方向に対する安定性を十分検討すべきであると考 える。そのためには，根趑が明確で合理的であり，かつ 誰にでもわかりやすい水平荷重の設定方法を確立する 必要がある。

\section{2 施工計画時の贸害防止対策}

前節では施工計画段階の災害防止対策について述べた が, 本項では施工時の災害防止対策について考察する。 前項で, 倒壊災害の原因として, 足場や支保工などが組 立図通りに組立てられていなかった，溶接の欠宿や出化 などにより部材の強度が不十分であったなど施工時の 問題について指摘した。しかし、これらは安全管理を十 分に行うことによりある程度防止できるものと考えら れる。最近になって風荷重に対する安全技術指針 ${ }^{13)}$ 見直されており，まずはこの指針などを遵守することが 倒壊災害防止の近道亡考元る。

安全管理によりある程度の災害は防止できるが, 例え ば強風について考えると，現場に 24 時間張り付いてい るわけには行かないので, 強風が発生することを予測で きなければ, 事例2のような深夜に発生した強風に対す る安全対策はできない。このような場合, 局地的な強風 を予測することが必要となるが, 現状では局地予報用の 観測網はなく、また,ドッブラーレーダー等による観测 を行わなければ, 局地的な強風之関連した上空の大気の 状態を钼測することができない(4)。このため, 局地的な 強風に対する数值予報は非常に困難なるのとなってお り，予期せぬ強風に前もって対応することは難しいもの と考えられる。このようことから，少し考え方を変える と, 予期せぬ強風などによる災害は少なからず発生する ものとして, 強風により一部の部材が破壊するようなこ とがあっても，むしろ，事例1に示したように，多くの死 傷者を出す大規模な倒塤に至らないような対策をとる ことも必要であると考える。

\section{3 建唋工事中の炎害のテータベースについて}

建設工事中の災害は，その被害者により異なる扱われ 方をしている。例えば建設業に従事する人が足場など の倒壊によって死傷する場合は労鲃災害であるが, 通行 人など建設業とは関係ない第三者が死偒した場合には 公膂災害として扱われている。その中で，本研究では， 建設工事中の風による災害について, 労德災害として取 り扱われたものを中心に調查を行った。特に，2章では 労倠災害のデータのみについて統計処理を行い, 公尨災 
害のデータについては取り上げなかった。本来なら，建 設工事中の全ての災害について統計処理を行うべきで あるが, 労働災害の場合には労働省の捜查管辖となり， 公策災害の場合には警察等の搜査管嘒となっており，労 㗢省や警察等がそれぞれ独自の集計・統計処理を行い， データの一元化が難しくなっているためである。この ことは，現在の縦割り行政の弊害とも言えるが，災害の 起因物（例えば足場や支保工）が同じでも被害を受け た人によって，労働災害や公衆災害というように扱う官 署が異なるということは問題である。

また，建設工事中の災害には，構造物や自動車等を損 傷するなど物的損害を与える場合もある。これらは，被 害を受けたものが建設業に関連したものかどうかで，人 的災害と同様に労伤災害か公衆災害に分けられる。物 的損害のみ生じた場合，災害として報告されることが少 ないため統計的処理は難しいが,これらの災害事例から も再発防止のための重要な問題点を得ることができる と考えられる。

このようなことから，被害を受けたものが何であるか には関わらず，災害の起因物を中心に考えて情報の収集 を行い，それに基づいて炎害防止対策を立てるべきであ ると考える。そのためには, 同一種類の災害の起因物に 対し労㗢省, 警察といった行政の枠を越え,さらには物 的損害のみの災害も加えた災害情報データベースを構 築し。これらを広く一般に公開することにより，官民一 体となって災害防止対策を行うことが必要である。こ れは, 本研究で問題とした建設工事中の風による災害だ けでなく，他の災害についても言えることである。

\section{6. まとめ}

建設工事中の風による労得災害を，建設業安全衛生年 鑑およびENRを中心に調查・分析した結果，以下のこ とがわかった。

（1）建設業での風による災害は，死亡災害の発生割合と しては小さいものの, 自然現象による災害に限っていえ ば，最も死亡者数の多い災害である。

(2) 我が国の重大災害の中で最も大きな問題である倒 壊災害の内，過去も近年も約 $10 \%$ は風によるものであ り変化がない。また，ENRに揭載された災害について も調べると，倒壊災害の内，風によるものが同様に約 10 \%を占めており，建設工事に関連した風による倒壊災害 は, 我が国と海外の共通の問題点であると考えられる。 （3）我が国の重大災害の中で, 1970 年代から近年にか けて, 風による施工中の構造物本体の倒塤災害は発生件
数が大きく減少したが, 足場の倒壊は発生件数にほとん ど変化がない。風に対する足場の安全対策は特に改善 されたわけではない。

（4）仮設構造物の設計に対する各種指針を見ると, 風荷 重, 地震荷重, 照查水平荷重といった考慮すべき水平荷 重の大きさや設計方法が明確に定義されておらず，㖟昧 になっている。しかし一方で, 重大災害に発展した倒壊 災害の内, 約 $40 \%$ が水平方向の安定性不足から生じて いたことから，根趣が明確で合理的であり，かつ誰にで もわかりやすい水平荷重の設定方法を確立する必要が ある。

（5）強風について考えると，現状では，局地的な強風に 対する数值予報は非常に困難なものとなっており，予期 せぬ強風に前もって対応することは難しいものと考え られる。この上うことから, 少し考え方を変えると, 強 風により一部の部材が破壊するようなことがあっても， むしろ,多くの死傷者を出す大規模な倒壊に至らないよ うな対策をとることも必要であると考える。

以上のことが本研究により得られたが，調查・分析の 過程で建設工事中の炎害に関し一元化されたデータベー スが無かった。特に，現在の綎割り行政の慗害により， 災害の起因物（例えば足場や支保工）が同じでも被害 を受けたものによって，労㗢災害や公衆災害というよう に扱う官署が異なっていた。このため，同一種類の災害 の起因物に対し，労伤省，整察といった行政の枠を越え た災害情報データベースを構筑し。これらを広く一般 に公開することにより，官民一体となって災害防止対策 を行うことが必要である。

\section{参考文献}

1）森 宜制, 木下鈞一, 小川勝教, 河尻義正: 強風に対 する足場等の安全対策, 産業安全研究所特別研究報 告, RIIS-SRR-81-1，1981.12.

2 ) 風荷重に対する鋼管足場等の安全技術指針，仮設工 業会, 1982.1 .

3) 建設業安全衛生年鑑, 建設業労働災害防止協会, 1972-81, 1989-98 (annual).

4) Engineering News-Record, McGraw-Hill, 1988-97 (weekly).

5) E.J.Hollis : Measurement of Wind Forces on Net Covered Temporary Scaffolds, Structural Safety \& Reliability, Vol.3, 1994, pp.1639-1646. 
6) S. Karshenas, A.H-S.Ang : A Structural Safety Analysis of Steel Buildings during Construction, Structural Safety, Vol.1, 1983, pp.239-255.

7 ) 河尻義正 : 災害事例一東京・大手町で強風により 足場が倒埢、安全工学, Vol.18, No.2, 1979, pp.110 $-112$.

8 ）仮設工業会, 建設業労倬災害防止協会 : 型わく支保 工・足場工事計画参画者資格研修テキスト，仮設工 業会, 1993, pp.173-174.

9）木下釷一,小川勝教, 河尻義正, 大幢勝利：仮設構 造物の倒壊防止のための力学的評価法に関する特 別研究, 産業安全研究所特別研究報告, RIIS-SRR $-91,1992.2$, pp.1-10.
10）鎦構造架設設計指針, 土木学会, 1978.5 .

11）期限付き構造物の設計・施工マニュアル・同解説 一各種建築物（膜構造・つり構造等）および工作 物, 日本建築学会, 1986.12 .

12）仮設構造物の計画と施工, 土木学会, 1990 .

13）風荷重に対する足場の安全技術指針，仮設工業会， 1999.2 .

14）朝倉正, 関口理郎, 新田尚 : 新版気象ハンドブック, 朝倉書店, $1995.11, \mathrm{p} 648$. 